\title{
Some roadside medicinal weeds as bio-indicator of air pollution in Kolkata
}

\author{
Pranabesh Ghosh*, Sirshendu Chatterjee, Suradipa Choudhury, Tanusree Sarkar, Ahana Sarkar, Susmita Poddar \\ Department of Biotechnology, Techno India University, West Bengal, Kolkata, West Bengal, India.
}

\begin{tabular}{|c|c|}
\hline ARTICLE INFO & ABSTRACT \\
\hline $\begin{array}{l}\text { Article history: } \\
\text { Received on: November 19, } 2020 \\
\text { Accepted on: December 26, } 2020 \\
\text { Available online: March 14, } 2021\end{array}$ & $\begin{array}{l}\text { Air pollution is a significant matter of concern in today's world. The current study objective is to determine the air } \\
\text { pollution tolerance index (APTI) of Kolkata from five roadside medicinal plants, namely, Heliotropium indicum, } \\
\text { Tridax procumbens, Cleome rutidosperma, Commelina benghalensis, and Euphorbia hirta. APTI was determined by } \\
\text { fresh leaves extracts using four important plants physiological parameters such as relative water content, ascorbic }\end{array}$ \\
\hline $\begin{array}{l}\text { Key words: } \\
\text { Air pollution tolerance index, } \\
\text { Ascorbic acid, } \\
\text { Chlorophyll, } \\
\text { Kolkata, } \\
\text { Medicinal weed, } \\
\text { pH, } \\
\text { Relative water content. }\end{array}$ & $\begin{array}{l}\text { acid (AA) content, total chlorophyll (Chl) content, and } \mathrm{pH} \text { of leaf extracts. Three sites or areas were selected for the } \\
\text { study in Kolkata. It includes a control area (Jadavpur), a moderately polluted area (Salt Lake, Sec V), and highly } \\
\text { polluted area (Dunlop Bridge) based on the West Bengal State Pollution Control Board databases and previous } \\
\text { study reports. For estimating Chl and AA content spectrophotometer and titration method were used, respectively. A } \\
\text { higher APTI value was found in plants located at the control area and moderately polluted area. However, the lower } \\
\text { amount of APTI value was found in plants located in the polluted area. The study concludes that air pollution has a } \\
\text { severe impact on plant and human health. The plant species with high APTI value can be planted around industrial } \\
\text { complexes, roadsides, and urbanized sites to monitor air pollution in greener and cost-effective way. }\end{array}$ \\
\hline
\end{tabular}

\section{INTRODUCTION}

Air pollution is a severe global problem faced by developing as well as developed nations. It is also an increasing threat to human health. Air pollution increases the chance for several health ailments and even mortality, approximately $9 \%$ of global mortality. Simultaneously it plays a vital role for other secondary health disorders and related deaths [1]. The close relationships among air pollution, particulate matters (PM), and human health such as heart disorders, pulmonary, and other associated diseases are discussed in several previous studies [2-4]. Current research highlighted that among the several environmental factors, the air pollution, primary causative agent for respiratory disorders such as bronchitis and asthma and it was noticed to aggravate the risk of infection by Severe Acute Respiratory Syndrome Coronavirus-2 (SARS-CoV-2) and the fatality of the COVID-19, particularly for infants and lactating women [5-8]. This may be due to air pollution's negative impact and the COVID-19 shares the same target, respiratory tracts, for their pathogenesis [9].

A considerable amount of smokes emitted from vehicles, household, and industries which are making India's metropolitan cities an intolerable location for living systems in the present scenario.

\footnotetext{
*Corresponding Author:

Pranabesh Ghosh, Department of Biotechnology, Techno India University, West Bengal, Kolkata, West Bengal, India.

E-mail: doctorpranabeshghosh@gmail.com
}

Therefore, it is mandatory to find out the places which are much polluted so that proper remedial steps can be taken to reduce the high air pollution level. Vehicles are the primary source of air pollutants such as carbon monoxide, nitrogen oxide, sulfur oxide, as well as suspended PM (SPM). Among different plans to control environmental pollution, absorption of several air pollutants (gaseous) by plants provides one of the best natural methods of cleaning the environment or urban atmosphere [10-14]. The forests or plantation naturally clears the environment by absorbing various gases and SPM through the leaves. Sensitive plants are suggested as prime biological indicators of air and environment pollution [15-17]. Plants sensitivity and responses toward different pollutants (gaseous and SPMs) are variable. Some species may be tolerant while others may be sensitive to air pollution. The much sensitive plant toward pollutants can play a bio-indicator of air or environment pollution [18].

Four biochemical and major plant physiological parameters such as ascorbic acid (AA) and total chlorophyll (Chl) content and leaf relative water content (RWC) as well as $\mathrm{pH}$ of leaf extracts were used to calculate the air pollution tolerance index (APTI). Understanding the responses or sensitiveness of plants to air and environment pollution at its physiological and biochemical level determination of APTI value is highly necessary. Environment planners and greenbelt developers can use the plants as bio-monitors to abate urban air pollution [11-13].

This current study aims at the determination of APTI from five common roadside medicinal weeds. For the study, three sites were selected from 
Kolkata. It includes a control area, a moderately polluted area, and highly polluted area based on the West Bengal State Pollution Control Board databases and previous study reports $[19,20]$. From the current research knowledge's and information, it can be stated that the present study is the first research investigation report on APTI in Kolkata Metropolitan City.

\section{MATERIALS AND METHODS}

\subsection{Chemicals}

The analytical reagent graded chemicals were used in the current experiments. For quantitative assays in the present study, a spectrophotometer (Systronics 117) was used to measure the particular optical density (OD).

\subsection{Study Site}

Kolkata is the highly populated metropolitan city (area of 1887 sq.km) with a population of 1.49 crores. The $3^{\text {rd }}$ most populous city in India positioned at $22.5726^{\prime} \mathrm{N}, 88.3639^{\prime}$ E. Kolkata is situated $9.15 \mathrm{~m}$ from the sea level. The areas which were selected for the current investigation from Kolkata include a control area Jadavpur (JP), a moderately polluted area Salt Lake, (SL) Sec V, and highly polluted area Dunlop Bridge (DB). The study was done in August and September month of 2019.

\subsection{Plants}

The plant species which were selected for the current study are given in Table 1 [21-24].

\subsection{Identification}

Five roadside medicinal weeds fresh leaves were collected from Salt Lake Sector-V, Kolkata, and authenticated by Botanical Survey of India.

\subsection{Determination of $\mathrm{Chl}$ Content}

Determination of Chl content was carried out by a standard method of D.I. Arnon (1949) [19,25-28]. Seventy milligrams of leaves samples were extracted using $10-15 \mathrm{ml}$ of $80 \%$ acetone solution, and it was centrifuged. The extracts' supernatant was collected in a separate falcon tube and it was repeated till the final residue becomes colorless. The final volume of the supernatant was made up to $30 \mathrm{ml}$. The OD was taken at a wavelength of $645 \mathrm{~nm}$ and $663 \mathrm{~nm}$ in triplicates. The amount of Chl content was determined by the help of the following formula:

Chl a (mg/g tissue): $[12.7 *(\mathrm{~A} 663)-2.69 *(\mathrm{~A} 645)] * \mathrm{FV} / 1000 * \mathrm{FW}$
Chl b (mg/g tissue): $[22.9 *(\mathrm{~A} 645)-4.68 *(\mathrm{~A} 663)] * \mathrm{FV} / 1000 * \mathrm{FW}$

Chl $(\mathrm{a}+\mathrm{b})(\mathrm{mg} / \mathrm{g}$ fresh tissue): [20.21*(A645) + 8.02* (A663)] * $\mathrm{FV} / 1000 * \mathrm{FW}$

$\mathrm{A}=$ Absorbance, $\mathrm{FV}=$ Final volume (Chl extracts), $\mathrm{FW}=$ Fresh weight (leaves extracts).

\subsection{Estimation of RWC}

The fresh plant leaves' RWC was determined with the standard method of Singh (1997) [29]. Leaves fresh weight was taken and it was immersed in water for overnight. Then, the leaves turgid weight was taken. Again the leaves were dried for an overnight period at $70^{\circ} \mathrm{C}$ and then finally the dry weight of the leaves was obtained. The RWC is calculated as:

$$
\mathrm{RWC}=(\mathrm{FW}-\mathrm{DW}) /(\mathrm{TW}-\mathrm{DW}) * 100
$$

Where, FW, TW, and DW indicates the fresh weight, turgid weight, and dry weight of the leaves samples

\subsection{Determination of $\mathbf{p H}$ of the Plant Leaves Extracts}

To evaluate the $\mathrm{pH}$ of plant leaves aqueous extracts, the standard method of Aremu et al., 2010 was used [30]. One gram of the fresh plant leaves was crushed in $10 \mathrm{ml}$ of double-distilled water, and then it was filtered. The $\mathrm{pH}$ was taken after calibrating the $\mathrm{pH}$ meter with a standard buffer solution of $\mathrm{pH}$ of 4 and 9.

\subsection{Estimation of AA Content}

The AA content was quantified using a standard iodine titration technique. Five grams of leaves were extracted with $100 \mathrm{ml}$ of doubledistilled water. A blue color formed and that persists up to $20 \mathrm{~s}$ of swirling. The final volume of the iodine solution was recorded. The calculation was carried out using the equation: $\mathrm{V}_{1} \mathrm{~S}_{1}=\mathrm{V}_{2} \mathrm{~S}_{2}$. The AA amount was showed in mg AA equivalent/g fresh weight $[31,32]$.

\subsection{Calculation of APTI}

The APTI values were evaluated using the following standard method (Singh and Rao, 1983) [33].

$$
\mathrm{APTI}=[\mathrm{AA}(\mathrm{Chl}+\mathrm{pH})+\mathrm{RWC}] / 10
$$

Where,

APTI $=$ Air pollution tolerance index

AA $=$ Ascorbic acid amount $(\mathrm{mg} / \mathrm{g})$

$\mathrm{Chl}=$ Total chlorophyll content $(\mathrm{mg} / \mathrm{g})$

$\mathrm{pH}=\mathrm{pH}$ of extracts (leaves)

RWC $=$ Relative water content of leaves (\%)

\subsection{Calculation of \% Reduction over Control (ROC)}

The $\%$ ROC value was calculated using the standard method $[11,13]$.

\subsection{Statistical Analysis}

The current experiments' measurements were done in triplicates and expressed as the averages of all the three statistical analyses \pm standard deviations. The means and standard deviations of the current research study results were calculated using MS Excel Software (Microsoft Corporation, Redmond, WA, USA).

Table 1: The plants' species selected for the present study.

\begin{tabular}{llll} 
Botanical name & Family & Common name & Local name \\
Heliotropium indicum & Boraginaceae & Indian heliotrope & Hatishur \\
Tridax procumbens & Asteraceae & Coat buttons & Tridhara \\
Cleome rutidosperma & Cleomaceae & Fringed spider flower & Nil Hurhure \\
Commelina benghalensis & Commelinaceae & Bengal day flower & Kanshira \\
Euphorbia hirta & Euphorbiaceae & Asthma plant & BoroKeru \\
\hline
\end{tabular}




\section{RESULTS}

The highest and lowest quantity of AA was observed in case of C. benghalensis at the control site (JP) and moderately polluted site (SL), and it is $10.56 \pm 1.45$ and $1.51 \pm 0.24 \mathrm{mg} / \mathrm{g}$ of $\mathrm{FW}$, respectively [Table 2]. Quantity of Chl was recorded as the highest amount in E. hirta at the control area (JP), and it is $9.64 \pm 0.08 \mathrm{mg} / \mathrm{g}$ of FW. The lowest content was observed in C. benghalensis at the polluted site (DB), and it is $1.53 \pm 0.01 \mathrm{mg} / \mathrm{g}$ of FW [Table 3]. The $\mathrm{pH}$ of the H. indicum was found to be the maximum at the control site (JP), and it is $8.65 \pm 0.04$. The minimum was observed in E. hirta at the moderately polluted site (SL), and it is $5.26 \pm 0.05$ [Table 4]. The maximum RWC was showed in C. benghalensis at the polluted site (DB), and it is $93.84 \pm 2.26 \%$, whereas the lowest value was observed in E. hirta at the control site (JP) and it is $36.60 \pm 5.18 \%$ [Table 5].

Table 2: Ascorbic acid content (mg/g of fresh weight) of plants leaves.

\begin{tabular}{lccc} 
Plant name & Jadavpur & Salt lake & Dunlop bridge \\
Heliotropium indicum & $4.94 \pm 0.82$ & $4.25 \pm 0.63$ & $3.29 \pm 0.41$ \\
Tridax procumbens & $1.92 \pm 0.24$ & $3.70 \pm 0.82$ & $2.06 \pm 0.41$ \\
Cleome rutidosperma & $6.31 \pm 1.26$ & $3.43 \pm 0.63$ & $1.78 \pm 0.63$ \\
Commelina benghalensis & $10.56 \pm 1.45$ & $1.51 \pm 0.24$ & $2.33 \pm 0.63$ \\
Euphorbia hirta & $3.84 \pm 0.63$ & $2.74 \pm 0.86$ & $6.72 \pm 0.63$ \\
\hline
\end{tabular}

Table 3: Total chlorophyll content ( $\mathrm{mg} / \mathrm{g}$ of fresh weight) of plants leaves.

\begin{tabular}{lccc} 
Plant name & Jadavpur & Salt lake & Dunlop bridge \\
\hline Heliotropium indicum & $3.79 \pm 0.18$ & $5.12 \pm 0.15$ & $3.82 \pm 0.13$ \\
Tridax procumbens & $3.01 \pm 0.15$ & $1.69 \pm 0.07$ & $1.80 \pm 0.05$ \\
Cleome rutidosperma & $3.41 \pm 0.25$ & $4.12 \pm 0.08$ & $2.14 \pm 0.06$ \\
Commelina benghalensis & $3.39 \pm 0.16$ & $7.05 \pm 0.01$ & $1.53 \pm 0.01$ \\
Euphorbia hirta & $9.64 \pm 0.08$ & $3.94 \pm 0.04$ & $2.02 \pm 0.33$ \\
\hline
\end{tabular}

Table 4: $\mathrm{pH}$ of plant leaves extracts.

\begin{tabular}{lccc} 
Plant name & Jadavpur & Salt lake & Dunlop bridge \\
Heliotropium indicum & $8.65 \pm 0.04$ & $7.38 \pm 0.06$ & $7.76 \pm 0.04$ \\
Tridax procumbens & $6.70 \pm 0.06$ & $6.09 \pm 0.04$ & $6.77 \pm 0.07$ \\
Cleome rutidosperma & $5.84 \pm 0.04$ & $5.68 \pm 0.04$ & $5.84 \pm 0.04$ \\
Commelina benghalensis & $6.60 \pm 0.05$ & $6.45 \pm 0.05$ & $6.51 \pm 0.06$ \\
Euphorbia hirta & $5.70 \pm 0.05$ & $5.26 \pm 0.05$ & $6.43 \pm 0.02$ \\
\hline
\end{tabular}

Table 5: Relative water content (\%) of plant leaves.

\begin{tabular}{lccc} 
Plant name & Jadavpur & Salt lake & Dunlop bridge \\
Heliotropium indicum & $75.80 \pm 6.40$ & $83.31 \pm 2.87$ & $43.92 \pm 3.37$ \\
Tridax procumbens & $82.68 \pm 3.52$ & $72.07 \pm 0.96$ & $66.30 \pm 3.04$ \\
Cleome rutidosperma & $62.57 \pm 7.67$ & $74.21 \pm 3.80$ & $70.78 \pm 5.61$ \\
Commelina benghalensis & $76.04 \pm 10.49$ & $73.46 \pm 1.51$ & $93.84 \pm 2.26$ \\
Euphorbia hirta & $36.60 \pm 5.18$ & $70.04 \pm 1.77$ & $37.34 \pm 0.82$ \\
\hline
\end{tabular}

The APTI of medicinal weeds was decreased from control to polluted sites except in case of $C$. benghalensis at the moderately polluted site (SL). The maximum reduction was observed at the highly polluted site (DB). The APTI of $H$. indicum showed a maximum decrease from control to the highly polluted site (DB), followed by C. benghalensis, C. rutidosperma, $T$. procumbens, and E. hirta. The mean \% reduction of APTI over control expressed maximum decrease in $C$. benghalensis and the lowest reduction in $T$. procumbens at the moderately polluted site (SL). The mean \% reduction of APTI over control described the maximum reduction in $H$. indicum and the lowest decrease in E. hirta at the highly polluted site (DB) [Table 6].

\section{DISCUSSION}

The decrease in AA content signifies the increased generation of reactive oxygen species at the time of photo-oxidation of $\mathrm{SO}_{2}$ to $\mathrm{SO}_{3}$. AA promotes several physiological and defense procedures and it is a potent reducing agent as a previous study reported that it has a crucial role in the decrease of $\mathrm{SO}_{2}$ [34]. $\mathrm{Chl}$ is the primary photosynthetic pigments. Its content determines the normal growth, function, and development of the entire ecosystem and biomass and the complete health condition of vegetation. Reduction in $\mathrm{Chl}$ amount indicates $\mathrm{SO}_{2}$ pollution. It is the main target of the gaseous pollutants such as $\mathrm{CO}, \mathrm{NO}_{2}$, and SPM [35]. In general, $\mathrm{pH}$ is an indicator of pollution level. It changes toward acidic range as the $\mathrm{SO}_{2}$ takes an entry to the leaf mesophyll tissues [11]. The current study results found some exceptions to these previous observations. RWC of a plant leaves helps control the normal physiological condition at various stress situations, and it indicates disturbed physiological states due to pollution [36,37]. APTI highly depends on plants' basic properties as the physiological and biochemical parameter levels vary highly from species to species $[11,38]$.

COVID-19 infection rate and air pollution observed to have strong interrelations among each other, and it has been reported at the pandemic periods from many parts of the world [39]. SARS-COV-2 induced lockdowns and restrictions had very positive effects on decreasing the air pollution level [40-42]. The places where air pollution level and patients with comorbidities were high are observed with an increased rate of infection and severity and mortality of SARS COV-2 compared to the less polluted regions among different age groups $[39,43,44]$. Minimum SARS-COV-2 fatality rate was found in vegetated or forested areas that indicate the importance cleanliness of environment from gaseous pollutants. This critical finding also suggests the vital immunoprotection by the Mediterranean plants [45]. The previous study also indicated that some important plant species have a high absorption capacity of particular air pollutants. APTI value is generally applied to measure various plants' susceptibility or resistance limits for specific gaseous pollutants. The plantation of greenery of tolerant plant species can resist air or environment pollution to a particular limit. APTI is applied to choose the tolerant plants specifically for decreasing the various air pollution modes in the urban surroundings of Kolkata Metropolitan City, which supports the present research investigation's main objectives, too [10-12]. From the

Table 6: Air pollution tolerance index and reduction over control (ROC \%) of plants leaves.

\begin{tabular}{|c|c|c|c|c|c|}
\hline Plant name & Jadavpur & Salt lake & $\%$ ROC & Dunlop bridge & $\%$ ROC \\
\hline Heliotropium indicum & 13.72 & 13.64 & 0.58 & 8.20 & 40.23 \\
\hline Tridax procumbens & 10.14 & 10.09 & 0.49 & 8.40 & 17.16 \\
\hline Commelina benghalensis & 18.16 & 9.39 & 48.29 & 11.26 & 37.10 \\
\hline Euphorbia hirta & 9.55 & 9.53 & 0.21 & 9.41 & 1.47 \\
\hline
\end{tabular}


current study results, it can be said that the medicinal weeds present in the highly polluted Metropolitan Cities with high APTI value may be able to reduce the severe COVID-19 infections and mortality rate and other respiratory disorders, too.

\section{CONCLUSION}

The present study results reflected the air pollutants positively influence that plant leaves' physiological and biochemical parameters. In the conclusion of the present study, it can be said that the plants with higher APTI value can be applied for the plantation in and around the industrial complexes, roadsides, and urbanized areas for reducing the heavy impact of air pollution. It will also help to decrease the chance of various human health ailments, including severe lung diseases.

\section{FUNDING}

External funding was not received for the work.

\section{CONFLICTS OF INTEREST}

The authors of the study declare that they have no conflicts of interest.

\section{AUTHORS' CONTRIBUTIONS STATEMENT}

Concept and Design, PG, SC; Data Acquisition, PG, SDC, TS, AS, SP; Data Analysis and Interpretation, PG, SDC, TS, AS, SP; Drafting Manuscript, PG, SDC, TS; Critical Revision, SC; Statistical Analysis, PG; Funding, No external funding received, chemical, and instruments support from the university, publication, and other fees from authors accumulated fund; Admin, Technical, or Material Support, Techno India University; Supervision, SC; Final Approval, PG, SC, SDC, TS, AS, SP.

Authors name abbreviated as Pranabesh Ghosh (PG), Sirshendu Chatterjee (SC), Suradipa Choudhury (SDC), Tanusree Sarkar (TS), Ahana Sarkar (AS), and Susmita Poddar (SP).

\section{REFERENCES}

1. Walker K State of Global Air 2019: Air Pollution a Significant Risk Factor Worldwide; 2020. Available from: https://www.healtheffects. org/announcements/state-global-air-2019-air-pollution-significantrisk-factor-worldwide. [Last accessed on 2020 Oct 04].

2. Kim KH, Kabir E, Kabir S. A review on the human health impact of airborne particulate matter. Environ Int 2015;74:136-43.

3. Tositti L, Brattich E, Parmeggiani S, Bolelli L, Ferri E, Girotti S. Airborne particulate matter biotoxicity estimated by chemometric analysis on bacterial luminescence data. Sci Total Environ 2018;640641:1512-20.

4. Thompson JE. Airborne particulate matter: Human exposure and health effects. J Occup Environ Med 2018;60:392-423.

5. Chafekar A, Fielding BC. MERS-CoV: Understanding the latest human corona virus threat. Viruses 2018;10:93.

6. Sharma VK, Jinadatha C, Lichtfouse E. Environmental chemistry is most relevant to study corona virus pandemics. Environ Chem Lett 2020;18:993-6.

7. Sun S, Han J. Unflushable or missing toilet paper, the dilemma for developing communities during the COVID-19 episode. Environ Chem Lett 2020;14:407-16.

8. Wang X, Han J, Lichtfouse E. Unprotected mothers and infants breastfeeding in public amenities during the COVID-19 pandemic. Environ Chem Lett 2020;18:1447-50.

9. Paital B, Agrawal PK. Air pollution by NO2 and PM2.5 explains COVID19 infection severity by over expression of angiotensinconverting enzyme 2 in respiratory cells: A review. Environ Chem Lett 2020;2020:1-18.

10. Bera B, Bhattacharjee S, Shit PK, Sengupta N, Saha S. Significant impacts of COVID19 lockdown on urban air pollution in Kolkata (India) and amelioration of environmental health. Environ Dev Sustainabil 2020;2020:1-28.

11. Kumar Kiran SJ, Sharu Raj KM, Deepalakshmi AP. Plants as bioindicators and Bio-monitors of Urban Air pollution. Int J Sci Eng Res 2016;7:449-55.

12. Sulistijorini R, Masud ZA, Nasrullah N. Tolerance levels of roadside trees to air pollutants based on relative growth rate and air pollution tolerance index. Hayati J Biosci 2008;15:123-9.

13. Deepalakshmi AP, Ramakrishnaiah H, Ramachandra YL, Radhika RN. Roadside plants as bio-indicators of urban air pollution. IOSR J Environ Sci Toxicol Food Technol 2013;3:10-4.

14. Varshney SR, Varshney CK. Response of peroxidase to low levels of $\mathrm{SO}_{2}$. Environ Exp Bot 1985;25:107-14.

15. Sharma PK, Pandey GC. Assessment of air pollution tolerance index of various roadside plant species around Ayodhya-Faizabad city of Uttar Pradesh, India. J Environ Bio Sci 2010;24:47-52.

16. Wagh ND, Shukla PV, Tamble SB, Ingle ST. Biological monitoring of roadside plants exposed to vehicular pollution in Jalgaon city. Environ Biol 2006;27:419.

17. Sadashivam S, Manikam S. Biochemical Methods in Agriculture. New Delhi: Eastern Publication; 1991.

18. Girish L, Krishnakutty K. Air pollution tolerance index of selected plants growing near roadside of a Navi Mumbai, Maharashtra. Int J Curr Res 2017;9:57807-11.

19. Mukherjee S, Chowdhury S, Ghosh P, Chatterjee S, Bhattacharya M. Air pollution has deep impact on plant pigments: A comparative study on differentially polluted areas of West Bengal. Poll Res 2018;37:690-3.

20. Available from: http://www.emis.wbpcb.gov.in/airquality/filter_for_ aqi.jsp. [Last accessed on 2020 Oct 04].

21. Ghosh P, Das C, Biswas S. Phytochemical composition analysis and evaluation of In Vitro medicinal properties and cytotoxicity of five wild weeds: A comparative study. F1000Res 2020;9:493.

22. Ghosh P, Chatterjee S. Evaluation of organoleptic, proximate parameters and analysis of nutritional composition of five wild weeds: A search for low cost nutraceuticals. Int J Pharm Sci Res 2020;11:5170-81.

23. Ghosh P, Biswas S, Dutta A, Biswas M, Das S, Das C, et al. Evaluation of phytochemical constituents and antioxidant property of leaf acetone extracts of five herbaceous medicinal weeds. J Pharm Sci Res 2019;11:2806-13.

24. Ghosh P, Saha M, Nandi S, Sengupta T, Kulavi S, Das S, et al. Green synthesis and characterization of silver nano-conjugates using some common medicinal weeds leaf aqueous extracts. Int J Pharm Sci Nanotechnol 2020;13:4752-8.

25. Rajalakshmi K, Banu N. Extraction and estimation of chlorophyll from medicinal plants. Int J Sci Res 2015;4:638-44.

26. Aron DI. Copper enzymes isolated chloroplasts, polyphenoloxidase in Beta vulgaris. Plant Physiol 1949;24:1-15.

27. Banik S, Mukherjee R, Ghosh P, Karmakar S, Chatterjee S. Estimation of plant pigments concentration from Tulsi (Ocimum sanctum Linn.): A six months study. J Pharmacogn Phytochem 2018;7:2681-4.

28. Ghosh P, Das P, Mukherjee R, Banik S, Karmakar S, Chatterjee S. Extraction and quantification of pigments from Indian traditional medicinal plants: A comparative study between tree, shrub, and herb. Int J Pharm Sci Res 2018;9:3052-9.

29. Singh A. Practical Plant Physiological. New Delhi: Kalyani Publishers; 1997.

30. Aremu MO, Olaofe O, Basu SK, Abdulazeez G, Acharya SN. Processed cranberry bean (Phaseolus coccineus L.), seed flour for 
the African diet. Can J Plant Sci 2010;90:719-28.

31. Majidi MI, Hazim Y. Determination of Vitamin C (ascorbic acid) contents in various fruit and vegetable by UV-Spectrophotometry and titration methods. J Chem Pharm Sci 2016;9:2972-4.

32. Available from: https://www.thoughtco.com/vitamin-c-determination -by-iodine-titration-606322. [Last accessed on 2020 Oct 04].

33. Singh SK, Rao DN. Evaluation of the Plants for Their Tolerance to Air Pollution. New Delhi: Proceedings Symposium on Air Pollution Control Held at IIT; 1983. p. 218-24.

34. Jyothi JS. Evaluation of air pollution tolerance index of selected plant species along roadsides in Thiruvananthapuram, Kerala. J Environ Biol 2010;31:379-86.

35. Tripathi AK, Gautam M. Biochemical parameters of plant as indicators of air pollution. J Environ Biol 2007;28:127-32.

36. Dedio W. Water relations in wheat leaves as screening test for drought resistance. Can J Plant Sci 1975;55:369-78.

37. Ramakrishnaiah H, Somashekar RK. Higher plants as biomonitors of automobile pollution. Ecol Environ Conserv 2003;9:337-43.

38. Thambavani SD, Sabitha MA. Variation in air pollution tolerance index and anticipated performance index of plants near a sugar factory: Implications for landscape-plant species selection for industrial areas. J Res Biol 2011;1:494-502.

39. Bashir MF, Ma BJ, Komal B, Bashir MA, Farooq TH, Iqbal N, et al. Correlation between environmental pollution indicators and
COVID-19 pandemic: A brief study in Californian context. Environ Res 2020;187:109652.

40. Paital B. Nurture to nature via COVID-19, a self-regenerating environmental strategy of environment in global context. Sci Total Environ 2020;729:39088.

41. Paital B, Das K, Behera TR. Social lockdown and ecological intervention for the prevention of the community spread of COVID 19. Cancer Res Stat Treat 2020;3:667-9.

42. Paital B, Das K, Parida SK. Inter nation social lockdown versus medical care against COVID-19, a mild environmental insight with special reference to India. Sci Total Environ 2020;728:138914.

43. Roviello V, Roviello GN. Lower COVID-19 mortality in Italian forested areas suggests immunoprotection by Mediterranean plants. Environ Chem Lett 2020;2020:1-12.

44. Dutheil F, Baker JS, Navel V. COVID-19 as a factor influencing air pollution? Environ Poll 2020;263:114466.

45. Dutheil F, Navel V, Clinchamps M. The indirect benefit on respiratory health from the world's effort to reduce transmission of SARSCoV-2. Chest 2020;2020:30689-9.

\section{How to cite this article:}

Ghosh P, Chatterjee S, Choudhury S, Sarkar T, Sarkar A, Poddar S. Some

roadside medicinal weeds as bio-indicator of air pollution in Kolkata. J App Biol Biotech. 2021;9(2):164-168. DOI: 10.7324/JABB.2021.9216 